\title{
Histopathological effects of silver nanoparticles in Rhamdia quelen after oral exposure
}

\author{
López-Barrera, E.A. ${ }^{1}$; Grötzner, S.R. ${ }^{2}$; Esquivel, L. ${ }^{3}$; Voigt, C.L. . $;$ CAmpos, S.X. ${ }^{4}$ \\ \& Oliveira Ribeiro, C.A. ${ }^{2 *}$ \\ ${ }^{1}$ Instituto de Estudios y Servicios Ambientales, Universidad Sergio Arboleda, Bogotá, Colombia \\ ${ }^{2}$ Universidade Federal do Paraná, Departamento de Biologia Celular PO Box: 19031 CEP:81.531-990 Curitiba, PR, Brazil \\ ${ }^{3}$ Estação de Piscicultura Panamá. PO Box: 03. CEP 88490-000. Paulo Lopes, SC, Brazil \\ ${ }^{4}$ Universidade Estadual de Ponta Grossa, Departamento de Química. Caixa Postal 992 CEP: 84030-900 Ponta Grossa, PR, Brazil
}

Received November 27, 2020; Accept October 21, 2021

\begin{abstract}
The studies about silver nanoparticles (AgNP) increased in the last years but few is known about their effects in Brazilian neotropical freshwater fish species. The current study investigated the effects of AgNP on adult silver catfish Rhamdia quelen after subchronic oral exposure. After nanoparticle (NP) size and area characterization fish were administrated with three different doses for 15 days $(0.03,0.3$ and $3 \mu \mathrm{g} g-1)$. The concentration of silver in liver and kidney was measured to evaluate the bioaccumulation and discuss its effects in the target organs. Liver bioaccumulated $15,1.7$ and $0.2 \%$ of administered doses while kidney bioaccumulated 1.33, 0.33 and $0.9 \%$ (respectively for $0.03,0.3$ and $3 \mu \mathrm{g} g-1$ ). The histopathological findings were considered in both organs to evaluate the effects of AgNP, according to Bernet's Lesion Index (BLI). Also were included the melano-macrophages center (MMC) and new nephrons (NN) counting respectively in liver and posterior kidney. The results revealed morphological injuries as inflammation in both studied organs and vascular congestion and steatosis in liver, in a concentration dependent way. The presence of AgNP in the tissues revealed the bioavailability of the nanoparticle while the damages and morphological disturbs showed the potential risk of exposure in $R$. quelen, even under environmental relevant concentrations.
\end{abstract}

Keywords: Biomarkers, histopathology, kidney, liver, oral exposure, bioassay

\section{INTRODUCTION}

The bioavailability of a high diversity of pollutants in the aquatic ecosystems including the emergent chemical is a major challenge to evaluate the risks of exposure. More recently, the number of studies to elucidate the toxic effects of metallic nanoparticles has increased (Al-Sid-Cheikh et al., 2019; Luz et al., 2020; Glinski et al., 2021), but the establishment of minimal limits of toxicological interaction are still scarce to biota. Silver nanoparticles (AgNP) are described as emergent pollutants with increased ability to cross biological barriers and to deliver silver ions inside cells (Stensberg et al., 2011; Magesky et al., 2017). According to Foldbjerg et al. (2011) and Volker et al. (2011) the increase of reactive oxygen species (ROS) can explain some morphological effects of $\mathrm{AgNp}$ in cells, while the affinity of silver with protein thiol groups or binding of AgNP to DNA bases are included as genotoxic effect in mammals' cells (Kim et al. 2010).

The estimated concentrations of AgNP in the aquatic environment are about 0.03 to $0.08 \mu g$ L-1 (Muller \& Nowack, 
2008), which is comparatively lower than the concentrations of toxic metals and organic pollutants reported in many water bodies. Silver nanoparticles (AgNP) are widely used in products as antimicrobial, medical applications, renewable energies, cleaning and sport products, food additives, cosmetics, electronic components, and environmental remediation (Fabrega et al., 2011). However, the presence of complex mixtures in the environment difficult the establishment of the risk of exposure to both, biota, and human population. Additionally, this nanoparticle can act as "Trojan horse" carrying other chemicals into the cell (Romanovskaya et al., 2011), increasing the risk of exposure also to other pollutants.

Silver nanoparticles can be toxic to biota, including fish (Fabrega et al., 2011; Volker et al., 2013; Al-Sid-Cheikh et al., 2019). The present study evaluated the effects AgNP on adult silver catfish ( $R$. quelen) after subchronic and oral exposure using histopathological findings as biomarkers of effects, including a characterization of NP and chemical analysis in target tissues (liver and kidney). The histopathological investigation it is particularly important in long term exposures because represent the consequences of low-level damages such as molecular and biochemical. Due to the lack of information about the effects of AgNPs in Brazilian fish species, the current study includes new approaches to discuss the presence of this contaminant in the environment.

\section{MATERIAL AND METHODS}

\section{Preparation and characterization of AgNP suspension}

Silver nanoparticles (Sigma/Aldrich, cod. 576832) with $<10 \mathrm{~nm}$, were suspended at $10 \mu \mathrm{g} \mathrm{ml}{ }^{-1}$ ultrapure water, sonicated ( 8 cycles of 2 min each, $100 \mathrm{~W}$ ) and stored at room temperature $\left(15-30^{\circ} \mathrm{C}\right)$. The stock suspension of AgNP was re-sonicated ( 3 cycles of $5 \mathrm{~min}$ each, $100 \mathrm{~W}$ ) prior to dilution in PBS to obtain the final test concentrations. AgNPs size was determined in transmission electron microscope images (JEOL JEM 1200 EXII), after 1:1 dilution in methanol $(100 \%)$ and spread on 300-mesh carbon cover copper grids. Additionally, the size and zeta potential were also analyzed in ZS90 MALVERN Zetasizer Nano ${ }^{\circledR}$.

\section{Chemical analysis of silver in the biological samples}

Samples of liver, anterior and posterior kidney previously frozen and preserved at $-80^{\circ} \mathrm{C}$, were defrosted $(0.5 \mathrm{mg})$ at room temperature, digested with $2 \mathrm{ml}$ concentrated $\mathrm{HNO}_{3}$ (AR grade; Fisher Scientific) and placed in Friedrich TE-128/6 Tecnal ${ }^{\circledR}$ digester at $200^{\circ} \mathrm{C}$ for $2 \mathrm{~h}$. After cooling, extracts were filtered on Whatman quantitative filter (No. 540) and transferred to $25 \mathrm{ml}$ round-bottom flasks, washed with Milli-Q deionized water and gauged in flasks. Silver was analyzed with a Flame Atomic Absorption Spectrometer (FAAS) Varian ${ }^{\circledR}$ model 240FS attached to Sample Preparation System (SPS3) and a Sample Introduction Pump System (SIPS). Calibration standards containing $1.00,0.75,0.50$ and 0.25 ppm were made up from a stock solution $\left(1,000 \mu \mathrm{g} \mathrm{ml}^{-1}\right)$ SpecSol ${ }^{\circledR}$ of silver. The bioaccumulation of $\mathrm{Ag}$ was calculated in percentages in liver and kidney considering the nominal dose.

\section{Experimental Design}

Forty-four adults silver catfish $R$. quelen $(98.4 \pm 21.4$ g) were kept in $1.0 \mathrm{~m}^{3}$ fish cage (eleven individuals per group) in the fish farm Piscicultura Panama (Santa Catarina State, Southern Brazil). Prior to exposure, the animals were anesthetized with $0.02 \%$ MS222 (Ethyl ether-3amino-benzoic acid, Sigma $\left.{ }^{\circledR}\right)$ and weighted. Oral gavages with AgNP suspension were performed every 5 days starting at day "0" until day $10^{\text {th }}$ corresponding to three test doses $\left(0.03,0.3\right.$ and $\left.3 \mu \mathrm{g} \mathrm{g}^{-1}\right)$ and control groups. The intermediated tested dose was described as neurotoxic to Danio rerio (Powers et al., 2011). Fish were fed daily with commercial pellet food containing $45 \%$ crude protein. The AgNP was diluted in phosphate-buffered saline (PBS, $\mathrm{pH}$ 7.2) used as vehicle and so in the control group to evaluate the manipulation of fish. Five days after the last gavage, fish were anesthetized with MS222 (0.02\%) and liver and kidney were sampled for analysis.

\section{Histopathological Procedures}

Light Microscopy: Liver, head and posterior kidney samples were preserved in ALFAC fixative solution (70\% ethanol, 4\% formaldehyde and 5\% glacial acetic acid) for 16 $\mathrm{h}$, dehydrated in a graded series of ethanol baths and xylene and embedded in Paraplast Plus resin (Sigma ${ }^{\circledR}$ ). Sections of $5 \mu \mathrm{m}$ thickness were obtained in microtome (Leica ${ }^{\circledR}$ ) stained with haematoxylin and eosin, mounted with Entellan (Merck $®)$ and analyzed according to Bernet et al. (1999) with modifications. Steatosis, melano-macrophages, and vascular congestion were included for liver while for kidney other parameters as glomeruli damages were considered. For each damage or lesion an importance factor, or condition weight $(w)$, was assigned based on the biological significance of the lesion, i.e., the degree in which a lesion may affect the normal functioning of a tissue or organ. Accordingly, the lesion index was applied using the following formula: $\mathrm{IL}=\sum$ (a $\mathrm{x} W$ ), where: $\mathrm{IL}=$ lesion index, $\sum$ alt $=$ sum of damages/changes, $\mathrm{a}=$ degree of occurrence and $\mathrm{W}=$ factor of importance. The Bernet's Lesion Index (LI) for liver and kidney was individually analyzed. Melano-macrophages centers (MMC) were counted on 15 randomly chosen fields in each liver slice using an eyepiece graticule coupled to a light microscope and expressed by number of cells $\mathrm{mm}^{-2}$ according to Rabitto et al. (2005). New nephrons (NN) were counted as suggested for posterior kidney tissue and results were reported in new nephrons per $\mathrm{mm}^{-2}$.

\section{Statistical data analysis}

To analyze histological biomarkers, morphological changes were applied to one-way ANOVA. Individuals 
were considered as replicates $(\mathrm{n}=11)$ for each treatment. Test post-hoc Tukey were used for differences in treatments with control. When necessary, test was applied post-hoc Dunnett and/or Tukey. Comparison with nonparametric KruskalWallis test was used to analyze biomarkers of MMC and NN. Statistical analyzes were performed using the R software, and assuming a value of $\mathrm{p}<0.05$ for statistical significance.

\section{RESULTS}

The AgNP characterization showed a size distribution in Transmission Electron Microscopy (TEM) ranged from 5 to $19 \mathrm{~nm}$, with most particles in the 5 to $12 \mathrm{~nm}$ range (Figure 1A). The surface area of individual nanoparticles ranged from 10.34 to $78.80 \mathrm{~nm}-2$ where the majority concentrated between 10 and $42 \mathrm{~nm}-2$ range (Figure 1B). Additionally, the results showed the presence of AgNP aggregates with more than 100 $\mathrm{nm}$ of diameter in all three tested concentrations. About $64 \%$ of nanoparticles had average size of $629.4 \mathrm{~nm}$ for the nominal concentration of $0.03 \mu \mathrm{g} \mathrm{ml}^{-1} ; 60.7 \%$ of particles had average size of $720 \mathrm{~nm}$ for $0.3 \mu \mathrm{g} \mathrm{ml}^{-1}$; and $23.7 \%$ had size larger than $1000 \mathrm{~nm}$ for $3 \mu \mathrm{g} \mathrm{ml}^{-1}$. Zeta potentials varied from -10.8 to $-15.4 \mathrm{mV}$, confirming the instability of AgNP suspensions and the tendency for aggregation.

The bioaccumulation of silver was observed in a concentration and time dependent way, where the bioaccumulation in liver was higher than found in kidney (Figure 2) but, both tissues decreasing the Ag concentration after 15 days of exposure inversely proportional do tested doses: 15, 1.7 and $0.2 \%$ (liver) and 1.33, 0.33 and 0.9 (kidney), respectively for $0.03,0.3$ and $3 \mu \mathrm{g} \mathrm{g}^{-1}$.

The Table 1 resume the histopathological findings considered in the current study. The damages or alteration in liver and kidney revealed a high diversity of morphological disturbs in both studied target organs, but not necessarily in a concentration dependent way. The highlight was the occurrence of inflammatory responses in both studied organs, including here the peritubular and perivascular granulomatosis (Figures $3 \mathrm{~B}$ and $\mathrm{D}, 4 \mathrm{E}$ and $5 \mathrm{E}$ ), or even leucocytes infiltration (3F and
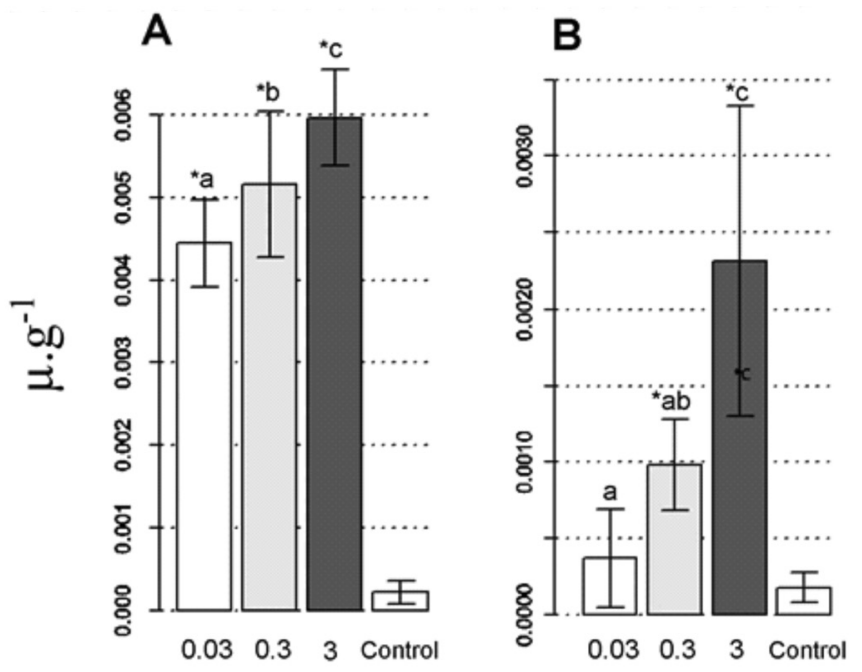

Figure 2. Chemical analysis of Ag in liver and kidney of $R$. quelen after oral exposure to silver nanoparticles $\left(0.03,0.3\right.$ and $\left.3 \mu \mathrm{g} \mathrm{g}^{-1}\right)$. Letters represent difference among tested groups and $(*)$ difference with the control group $(\mathrm{p}<0.05)$.

4c). In liver the presence of vascular congestion (Figure 3C) was found in individuals from all tested concentrations while the occurrence of basophilic foci was higher in individuals exposed to $3 \mu \mathrm{g} \mathrm{ml}^{-1}$ (Figure 3E). Steatosis and hemorrhage were found in individuals exposed to higher and lower tested concentrations respectively (Figures $3 \mathrm{~B}, 3 \mathrm{D}$ and $3 \mathrm{H}$ ) but necrosis were found in all tested groups including control (Figure 3G).

The erythrocyte concentration (Figure 4C) is common in head kidney, but this finding was frequent in individuals exposed to AgNP, also observed by the presence of center for erythrocytes degeneration (Figure 4D). Necrosis (Figure 4C), hemorrhage (Figure 4D) and vascular enlargement were also found.

The posterior region of kidney presents the function of blood filtration and excretion in fish. The alterations described in this part of kidney revealed drastic alteration in the nephron system, including severe damages in glomeruli (Figures 5B, $\mathrm{C}$ and $\mathrm{D}$ ) and in the tubules (Figures $5 \mathrm{E}$ and F), or in vessels

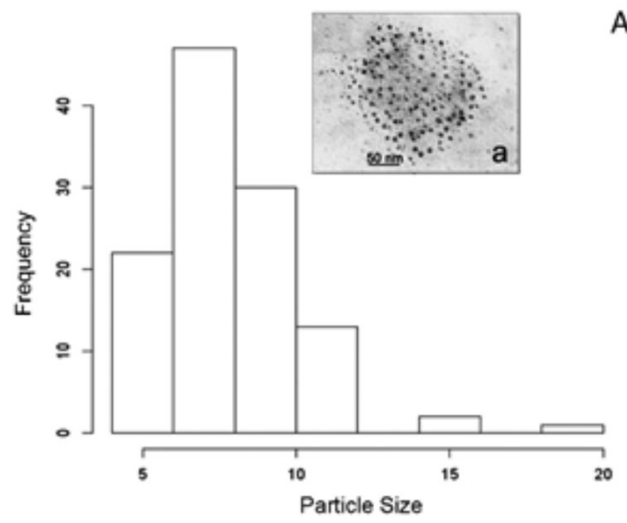

A

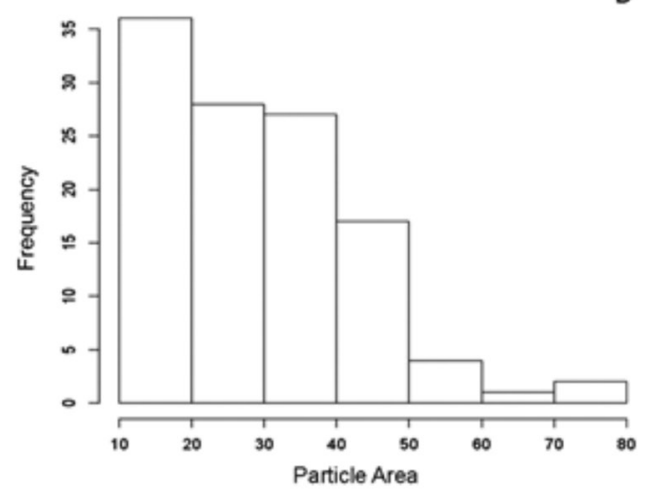

Figure 1. Characterization of silver nanoparticle (AgNP) size using transmission electron microscopy (TEM). (A) Histogram of size (nm) distribution of silver nanoparticles demonstrate an average size of $7.83 \pm 2.21 \mathrm{~nm}$ and (B) a surface area $\left(\mathrm{nm}^{2}\right)$ of $28.92 \pm 13.69 \mathrm{~nm}$. 
Table 1. Occurrence of morphological damages in liver and kidney of $R$. quelen after oral exposure to silver nanoparticles

\begin{tabular}{|c|c|c|c|c|}
\hline \multirow[t]{2}{*}{ Morphological damages } & \multicolumn{4}{|c|}{ Occurrence (\%) } \\
\hline & Control & $\mathbf{0 . 0 3 \mu g} \mathrm{g}-1$ & $\mathbf{0 . 3} \mu \mathrm{g} g-1$ & $3 \mu \mathrm{g} \mathrm{g}-1$ \\
\hline & \multicolumn{4}{|c|}{ Liver } \\
\hline Vascular congestion & 9 & 64 & 55 & 55 \\
\hline Perivascular granulomatosis & 0 & 18 & 9 & 9 \\
\hline Peritubular granulomatosis & 0 & 9 & 0 & 0 \\
\hline Basophilic foci & 0 & 9 & 9 & 36 \\
\hline Leucocyte infiltration & 0 & 73 & 72 & 91 \\
\hline Steatosis & 0 & 0 & 0 & 9 \\
\hline Hemorrhage & 9 & 9 & 0 & 0 \\
\hline \multirow[t]{2}{*}{ Necrosis } & 9 & 21 & 33 & 64 \\
\hline & & Head kidney & & \\
\hline Erythrocytes concentration & 9 & 9 & 18 & 9 \\
\hline $\begin{array}{l}\text { Center for Erythrocytes } \\
\text { degeneration }\end{array}$ & 18 & 64 & 45 & 63 \\
\hline Necrosis & 9 & 55 & 0 & 9 \\
\hline Hemorrhage & 9 & 0 & 19 & 0 \\
\hline \multirow[t]{2}{*}{ Erythrocytes concentration } & 9 & 9 & 18 & 9 \\
\hline & & Posterior kidne & & \\
\hline Glomeruli alteration & 9 & 72 & 55 & 45 \\
\hline Tubular alteration & 0 & 64 & 18 & 9 \\
\hline Granulomatosis perivascular & 0 & 18 & 18 & 0 \\
\hline Granulomatosis peritubular & 0 & 9 & 18 & 0 \\
\hline Necrosis & 9 & 9 & 0 & 0 \\
\hline
\end{tabular}
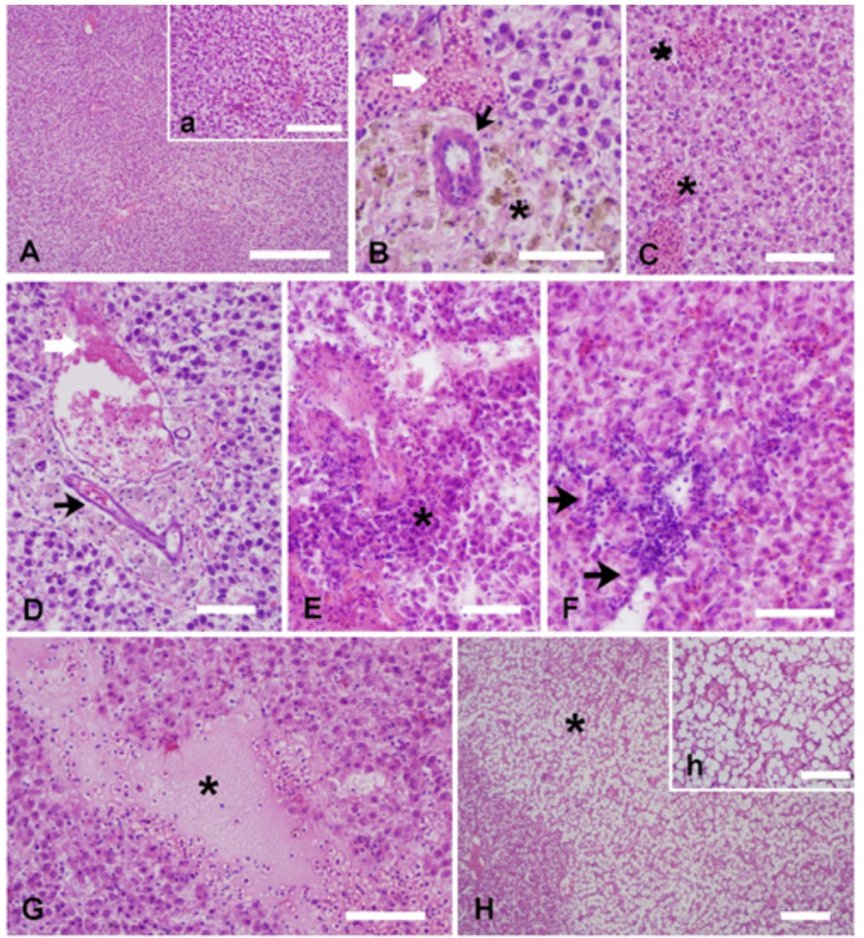

Figure 3. Liver cross section of $R$. quelen after oral exposure to AgNP. A. Control group (scale bar $=250$ and detail, $100 \mu \mathrm{m}$ ); B. occurrence of peritubular granulomatosis (black arrow) and hemorrhage (white arrow), observe the presence of melano-macrophage centers $(*) ;$ C. the $(*)$ represent vascular congestion; D. tissue damages showing hemorrhage (with arrow) and perivascular granulomatosis (black arrow); E. the (*) identify a basophilic focus; F. the arrows showed the presence of inflammatory response; G. large necrosis area $(*)$ while in $(\mathrm{H}, \mathrm{h})$ is observed an area of intense steatosis (*) (B, C, D, E, F, G and H scale bar $=50 \mu \mathrm{m}, \mathrm{h}$ scale bar $=100 \mu \mathrm{m})$. Hematoxylin and Eosin stains.
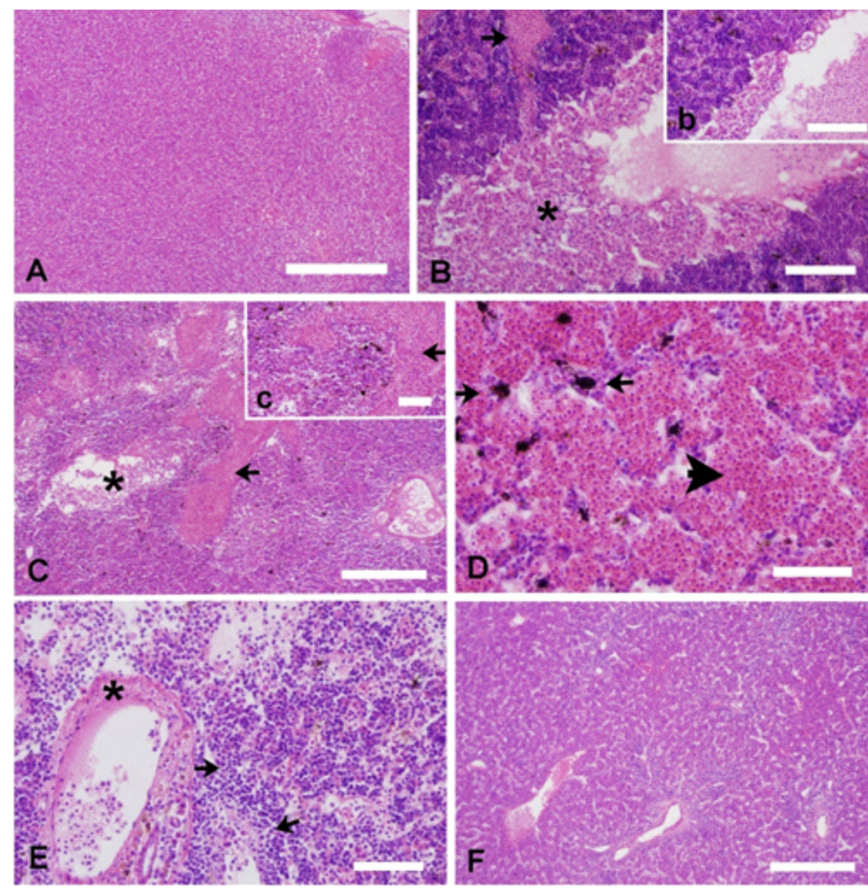

Figure 4. Head kidney cross section of $R$. quelen after oral exposure to AgNP. A. Control showing the general aspect of tissue; B. transition tissue between head $(*)$ and posterior (arrow). Observe the presence of necrosis in head kidney; C. damages observe in the parenchyma as necrosis $(*)$ and intense regions of erythrocytes degeneration (black arrow). The white arrow showed a perivascular granulomatosis; D. observe the high concentration of erythrocytes and black deposits (small arrow); E. the arrows showed a more dispersed parenchyma while the $\left(^{*}\right)$ represent a perivascular granulomatosis; F. a vascular enlargement is observed in the parenchyma. (Scale bar A and $\mathrm{F}=250 \mu \mathrm{m}, \mathrm{b}=100 \mu \mathrm{m}, \mathrm{B}, \mathrm{C}, \mathrm{D}$ and $\mathrm{E}=$ $50 \mu \mathrm{m})$. Hematoxylin and Eosin stains. 
(Figure 5E and $\mathrm{G}$ ) including the interrenal cells (Figure 5H). The inflammatory response was observed in the vessels as perivascular granulomatosis (Figure 5E and $\mathrm{F}$ ).

The Bernet's Lesion Index (LI) revealed the toxicity of all tested doses in liver and kidney of $R$. quelen. The liver was the organ most affected (Figure 6A) showing high LI, differently than observed to kidney (Figure 6B). In posterior kidney the LI present high values in individuals exposed to the lower dose, differently than observed to liver (Figure 6C). The presence of melano-macrophage centers was higher in posterior kidney comparatively with liver or head kidney (Figure 6D), while the counting of new nephrons increases in individuals exposed to higher doses in posterior kidney (Figure 6E).

\section{DISCUSSION}

The histopathological findings are at least the results of protective cell mechanisms failure reflecting molecular and biochemical disturbs that reflect injuries in cell or tissues. These endpoints are biomarkers of effects to evaluate the risk of exposure to pollutants in target organs as liver and kidney in biomonitoring programs. In general, these findings
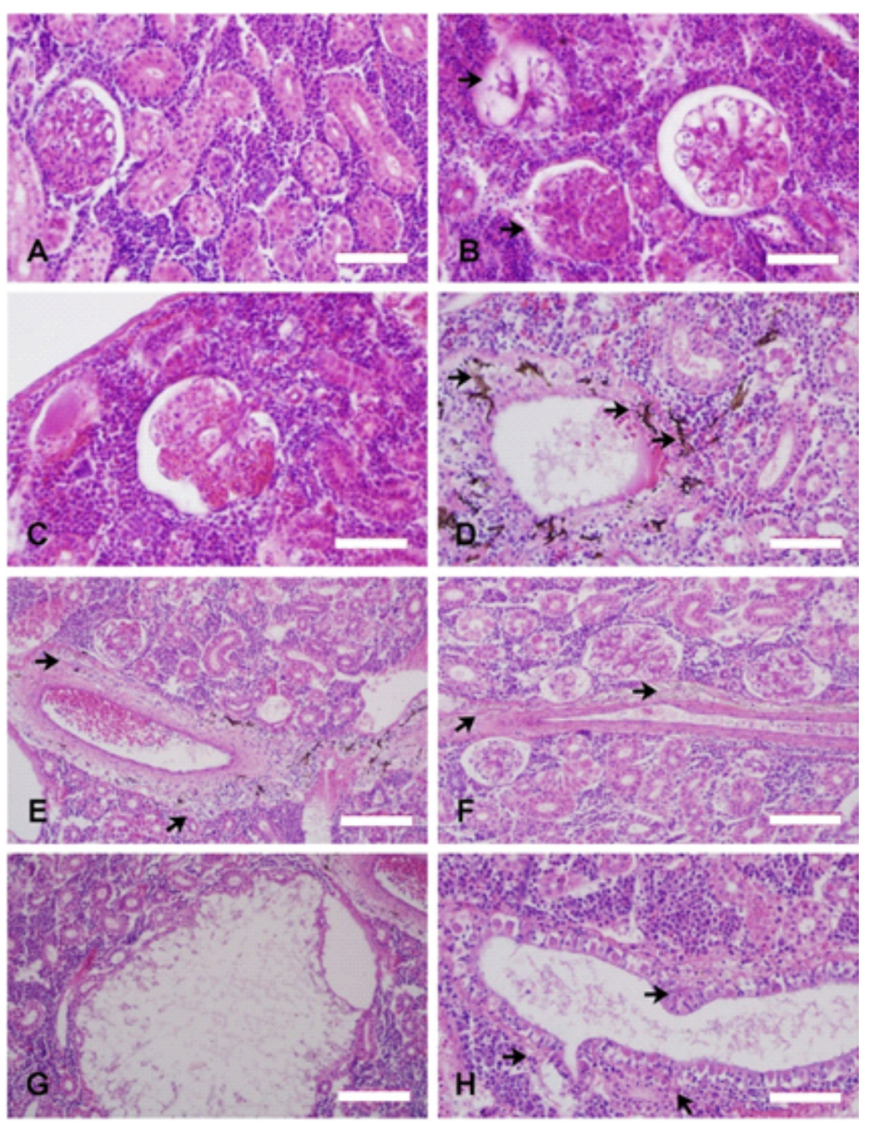

Figure 5. Posterior kidney cross section of $R$. quelen after oral exposure to AgNP. A. control, observe the normal glomeruli (*); B. the arrow shows a degenerated glomerulus while the $(*)$ show an altered glomeruli with an expressive capillary and Bowman space dilatation also observed in (C); D. the $(*)$ indicates the presence of perivascular granulomatosis $(*)$, also found in (E) and (F), while the interenal cells damage is observed in (D) and (H)

(arrows); in $\mathrm{F}$ the ${ }^{*}$ ) represent altered glomeruli. (Scale bar $=50 \mu \mathrm{m}$ ). Hematoxylin and Eosin stains. can develop to physiological disturbs leading individuals to develop diseases or even death, decreasing the population size. The present results showed the risk of exposure to AgNP and aggregates inducing severe damages in two important target organs of $R$. quelen, a native Brazilian species.

The characterization of AgNP also showed the presence of particles in aggregates larger than $100 \mathrm{~nm}$, which can be explained by the low zeta potential values. It is interesting from the perspective of environmental toxicology, since several environmental factors affect the kinetics of aggregation of nanoparticles in the field, such as: organic matter (Huynh \& Chen, 2011), solar radiation (Cheng et al., 2011) and solubility (Zhang et al., 2011). According to Tejamaya et al. (2012), most of AgNPs are present as aggregates in the field, and so the results reported in the current study represent an environmental significant way.

The chemical analysis showed the bioavailability of AgNP in a concentration dependent way for both studied target organs and established that liver is more susceptible than kidney. This result confirms the liver as an important target organ for AgNP effects after oral exposure. In other hand, the bioaccumulation in kidney is nominally lower but also suggest this organ as an important excretion route for $\mathrm{Ag}$ or even $\mathrm{AgNP}$, and so a potential target tissue to evaluate its effects.

The high diversity of damages or disturbs described to liver and kidney of $R$. quelen revealed the sensibility of the species to oral exposure of AgNP, even if the tested doses are environmentally significant. The inflammatory response
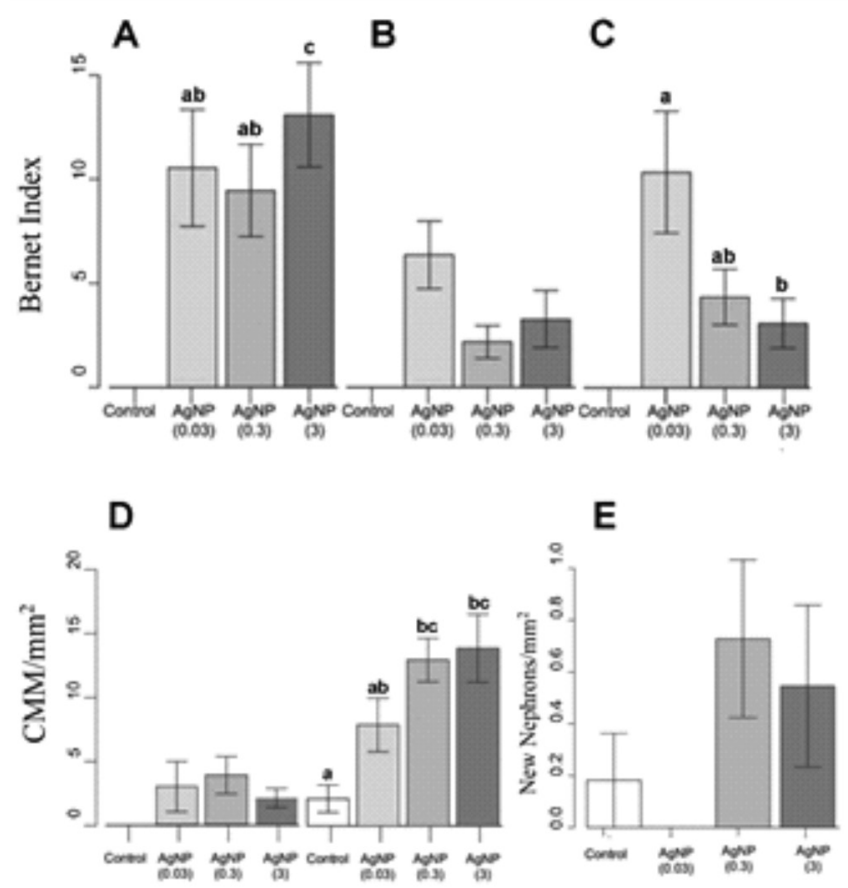

Figure 6. Indexes of histopathological findings in R. quelen after oral exposure to silver nanoparticles. Bernet's Lesion Index in liver (A), head kidney (B) and posterior kidney(C); (D) occurrence of Melano-macrophages centers in liver and posterior kidney respectively (E) occurrence of new nephrons in posterior kidney. $(\mathrm{p}<0.05) . \mathrm{CMM}=$ Melano-macrophage Center. The letters indicate the difference among tested groups. 
found in both organs shows that cell injury or tissue damages are important findings to study the exposure of fish to AgNP, as the occurrence was present in individuals from all tested doses. The presence of granulomatosis perivascular in liver and kidney is an important finding to explain the route of AgNP to liver and represent an effect that can lead to physiological disturbs to the organ. According to Matushima et al. (2006), changes such as vascular congestion, leukocyte infiltration and peri-vascular and peribiliary granulomatosis are associated with protection of tissue as a primary immune response. Additionally, the presence of vascular congestion, hemorrhage and vascular dilatation strongly suggest the fragility of circulatory system in $R$. quelen after exposure to AgNP. Gernhöfer et al. (2001) described that teleost liver is the primary organ in xenobiotic transformation, storage, or elimination of chemicals, making the hepatocellular damages typical responses against pollutants exposure. The injuries as necrosis are permanent damages and in liver can decrease the hepatic function with expressive consequence to organ physiology. This event represents an irreversible structural and functional damage and is a consequence of many cell disorders. According to Mela et al. (2013) enzyme disturbs, protein synthesis, oxidative stress or cell membrane integrity loss are a set of events responsible for necrosis. The presence of steatosis revealed physiological disturbs of cell function, where the fat accumulation may indicate a disarrange of cytoskeleton with consequence for the vesicles traffic or even a disturb in the metabolism. According to Giari et al. (2007) the presence of steatosis can be also classified as a prenecrotic stage already observed in fish exposed to pollutants including metals. Additionally, the basophilic foci mean the high susceptibility for phenotypic changes increasing the permanent effects and putting in risk the integrity of the organ.

The increased number of melano-macrophage centers observed in hepatic tissue of individuals exposed to AgNP, demonstrated that animals are responding to the observed tissue damages by defensive processes and inflammatory events (Gagné et al., 2012). Additionally, Pacheco \& Santos (2002) described the presence of melano-macrophage centers with degenerative and necrotic processes in fish. In the current study, due to the oral route of exposure to AgNPs it is expected the related adverse effects in liver and kidney, as observed for other toxic metals leading to cell death. This would explain a pattern of inflammatory response found by different kinds of changes or lesions in hepatic and renal tissues. Particularly, the alterations observed in vessels suggest that the oral exposure is an important route for AgNP in fish and it also reveals the circulatory system as potential targets.

The head kidney in fish present both hematopoietic and endocrine functions and the effects observe in the current study highlight this organ as an important target to AgNP. The negative effects described after AgNP exposure on this tissue revealed disturbs that can disable some functions as erythrocyte destruction by the occurrence of necrosis and the increase areas of red blood cells degeneration. Additionally, as described to liver above, the presence of hemorrhage and vascular dilatation, confirm the circulatory effects of AgNP also to kidney. The hematopoietic is noted by the occurrence of centers for erythrocytes destruction and melano-macrophage centers, increased with the exposure in individuals from all tested doses. According to Agius \& Roberts (2003) these findings are associated with lesions of chronic inflammation. Despite of the damages and alterations described to head kidney, the Bernet's Lesion Index (LI) were not different among the tested doses, differently from observed to posterior kidney, where individuals exposed to the lower dose showed the higher LI.

Differently than observe in other studies kidney presented a large amount of morphological alteration, showing the sensibility of the organ to AgNP exposure, especially in posterior section. This distinct regions of kidney in fish means different physiological role highlighting the organ as an important target to pollutants. The posterior kidney section in fish is responsible to regulate the waste excretion eliminating toxic molecules, salt and water homeostasis (Davidson, 2014) or even pollutants. This part of urinary system in fish was quite affected by AgNP showing drastic damages in glomeruli, significantly compromising the nephron function. Fish can modulate the loss of nephrons by the development of new nephrons, suggesting a 'neo-nephrogenic' process that recapitulates conserved pathways utilized during vertebrate kidney organogenesis (Diep et al., 2011). This is an interesting biomarker for renal effects of pollutants including chronic or acute exposure (Davidson, 2014). Although the counting of new nephrons was not significantly different among tested doses or control group, the present results showed an increase in the number from individuals exposed to higher doses in relation with the lower dose. The persistence of nephrons progenitors found in fish can explain the high LI found in individuals exposed to higher doses, suggesting an more intensity of tissue regeneration.

Finally, the present study reported liver and kidney injuries observed in $R$. quelen related to AgNP after oral and subchronic exposure. The bioaccumulation of $\mathrm{Ag}$ in liver and kidney confirms these organs as target to AgNP exposure and explain partially the injuries observed in both tissues. Overall, the histopathological markers reflected a poor health status of the fish and showed that further studies are necessary to understand the risk of exposure of AgNP to Brazilian and other fish species.

\section{ACKNOWLEDGMENTS}

CAPES (Brazilian Ministry Educational Council) for fellowship assistance, CNPq (Brazilian Agency for Science and Technology) and Araucaria Foundation (Parana State Agency for Science and Tecnhology) for grants; and Electron Microscopy Center at Federal University of Paraná for technical support.

\section{REFERENCES}

AGIUS, C., \& ROBERTS, R.J. 2003. Melano-macrofhage centers in their role in fish pathology. J. Fish Dis. 26: 499-509. http:// dx.doi.org/10.1046/j.1365-2761.2003.00485.x 
AL-SID-CHEIKH, M., ROULEAU, C., BUSSOLARO, D., OLIVEIRA RIBEIRO, C.A., \& PELLETIER, E. 2019. Tissue Distribution of Radiolabeled $110 \mathrm{~m} \mathrm{Ag}$ Nanoparticles in Fish: Arctic Charr (Salvelinus alpinus). Environ. Sci. Technol. 53: 12043-12053. http://dx.doi.org/10.1021/acs.est.9b04010

BERNET, D., SCHIMIDT, H., MELER, W., BURKHARDTHOLM, P., \& WAHLI, T. 1999. Histopathology in fish: proposal for a protocol to assess aquatic pollution. J. Fish Dis. 22: 25-34. https://doi.org/10.1046/j.1365-2761.1999.00134.x

CHENG, Y.W.; YIN, L.Y., LIN, S.H., WIESNER, M., BERNHARDT, E., \& LIU, J. 2011. Toxicity reduction of polymer-stabilized silver nanoparticles by sunlight. J. Phys. Chem. C. 115: 4425-4432. https://doi.org/10.1021/jp109789j

DAVIDSON, A.J. 2014. Kidney Regeneration in Fish. Nephron Exp. Nephrol. 126:45-49. https://doi.org/10.1159/000360660

DIEP, C.Q., MA, D., DEO, R.C., HOLM, T.M., NAYLOR, R.W., ARORAM N., WINGERT, R.A., BOLLIG, F., DJORDJEVIC, G., LICHMAN, B., ZHU, H., IKENAGA, T., ONO, F., ENGLERT, C., COWAN, C.A., HUKRIEDE, N.A., HANDIN, R.I., \& DAVIDSON, A.J. 2011. Identification of adult nephron progenitors capable of kidney regeneration in zebrafish. Nature. 470: 95-100. http://dx.doi.org/10.1159/000360660

FABREGA, J., LUOMA S.N., TYLER, C.R., GALLOWAY, T.S., \& LEAD, J.R. 2011. Silver nanoparticles: Behaviour and effects in the aquatic environment. Environ. Internat. 37 (2): 517-531. http://dx.doi.org/10.1016/j.envint.2010.10.012

FOLDBJERG, N.M., DANG, D.D., \& AUTRUP, H. 2011. Cytotoxicity and genotoxicity of silver nanoparticles in the human lung cancer cell line A549. Arch. Toxicol. 85: 743-750. http://dx.doi.org/ 10.1007/s00204-010-0545-5

GAGNÉ, F., ANDRÉ, C., SKIRROW, R., GÉlINAS, M., AUCLAIR J., VAN AGGELEN, G., TURCOTTE, P., \& GAGNON, C. 2012. Toxicity of silver nanoparticles to rainbow trout: a toxicogenomic approach. Chemosphere. 89: 615-622. http://dx.doi.org/10.1016/j.chemosphere.2012.05.063

GERNHÖFER, M., PAWET, M., SCHRAMM, M., MÜLLER, E., \& TRIEBSKORN, R. 2001. Ultrastructural biomarkers as tools to characterize the health status of fish in contaminated streams. J. Aqua. Ecosyst. Stress. Recov. 8: 241-260.

GIARI, L., MANERA, M., SIMONI, E., \& DEZFULI, B.S. (2007) Cellular alterations in different organs of European sea bass Dicentrarchus labrax (L.) exposed to cadmium. Chemosphere. 67:1171-1181. http://dx.doi.org/10.1016/j. chemosphere.2006.10.061

HUYNH, K.A., \& CHEN, K.L. 2011. Aggregation kinetics of citrate and polyvinylpyrrolidone coated silver nanoparticles in monovalent and divalent electrolyte solutions. Environ. Sci. Tech. 45 (13): 5564-5571. http://dx.doi.org/10.1021/es200157h

KIM, Y.J., YANG, S.I., \& RYU, J.C. 2010. Cytotoxicity and genotoxicity of nanosilver in mammalian cell lines. Mol. Cell Toxicol. 6: 119-125. http://dx.doi.org/10.1007/s13273-0100018-1

MAGESKY, A., OLIVEIRA RIBEIRO, C.A., BEAULIEU, L., \& PELLETIER, E. 2017. Silver nanoparticles and dissolved silver activate contrasting immune responses and stress-induced heat shock protein expression in sea urchin. Environ. Toxicol. Chem. 36(7): 1872-1886. http://dx.doi.org/10.1002/etc.3709
MATUSHIMA, E.R., FILHO, L., KANAMURA, A., TAKAMI, C., \& SINHORINI, I.L. 2006. Experimental chronic granulomatous inflammatory process in fish: a morphological, ultrastructural and immunocytochemical study. Braz. J. Vet. Res. Anim. 43(2):152-158. https://doi.org/10.1590/1414431X20143735

MELA, M., GUILOSKI, I.C., DORIA, H.B., RANDI, M.A., OLIVEIRA RIBEIRO, C.A., PEREIRA, L., MARASCHI, A.C., PRODOCIMO, V., FREIRE, C.A., \& SILVA DE ASSIS, H.C. 2013. Effects of the herbicide atrazine in neotropical catfish (R. quelen). Ecotoxicol. Environ. Safety. 93: 13-21.http://dx.doi. org/10.1016/j.ecoenv.2013.03.026

MULLER, N.C., \& NOWACK, B. 2008. Exposure modelling of engineered nanoparticles in the environment. Environ Sci Tech 42: 4447-4453. http://dx.doi.org/10.1021/es7029637

PACHECO, M., \& SANTOS, M.A. 2002. Biotransformation, genotoxic, and histopathological effect of environmental contaminants in European eel (Anguilla anguilla L.). Ecotoxicol. Environ. Safety. 53:331-347. http://dx.doi.org/10.1016/s01476513(02)00017-9

POWERS, C.M., SLOTKIN, T.A., SEIDLER, F.J., BADIREDDY, A.R., \& PADILLA, S. 2011. Silver nanoparticles alter zebrafish development and larval behavior: Distinct roles for particle size, coating and composition. Neurotoxicol. Teratol. 33(6): 708-14. http://dx.doi.org/10.1016/j.ntt.2011.02.002

RABITTO, I.S., ALVES COSTA, J.R.M., SILVA DE ASSIS, H.C., PELLETIER, È., AKAISHI, F.M., ANJOS, A., RANDI, M.A.F., \& OLIVEIRA RIBEIRO, C.A. 2005. Effects of dietary $\mathrm{Pb}$ (II) and tributyltin on neotropical fish, Hoplias malabaricus: histopathological and biochemical findings. Ecotoxicol. Environ. Safety. 60: 147-156. http://dx.doi.org/10.1016/j. ecoenv.2004.03.002

ROMANOVSKAYA, G.I., OLENIN, A.Y., \& VASILEVA, S. Y. 2011. Concentration of polycyclic aromatic hydrocarbons by chemically modified silver nanoparticles. Rus. J. Phys. Chem. A, Focus on Chemistry. Vol 85(2): 274-278. http://dx.doi. org/10.1134/S0036024411010237

STENSBERG, M.C, WEI Q., MCLAMORE, E.S., PORTERFIELD, D.M., WEI, A., \& SEPÚLVEDA, M.S. 2011. Toxicological studies on silver nanoparticles: challenges and opportunities in assessment, monitoring and imaging. Nanomedicine. 6(5):879-898. http://dx.doi.org/10.2217/ nnm. 11.78

TEJAMAYA, M., ROMER, I., MERRIFIELD, R.C., \& LEAD, J.R. 2012. Stability of Citrate, PVP, and PEG Coated Silver Nanoparticles in Ecotoxicology Media. Environ. Sci. Technol. 2012, 46, 13, 7011-7017. https://doi.org/10.1021/ es2038596

VOlKer, C., OETKEn, M., \& OEHLMANN, J. 2013. The Biological effects and possible modes of action of nanosilver. Rev. Environ. Contam. Toxicol. Vol 223: 81-106. http://dx.doi. org/10.1007/978-1-4614-5577-6_4

ZHANG, W., YAO, Y., LI, K., HÜANG, Y., \& CHEN, Y. 2011. Influence of dissolved oxygen on aggregation kinetics of citratecoated silver nanoparticles. Environ. Poll. 159 (12):3757-62. http://dx.doi.org/10.1016/j.envpol.2011.07.013 